\title{
PELAKSANAAN PENCATATAN DOKUMEN KELUARGA BERBASIS SISTEM INFORMASI ADMINISTRASI KEPENDUDUKAN (SIAK) DALAM MEWUJUDKAN TERTIB ADMINISTRASI KEPENDUDUKAN DI DESA SENARU
}

Muammar Kadafi, Mukarromah Hulloh2, Dita Ademulani3 , I Gusti Ngurah A. R.4, Nuri Hilmiati5, Medina Sophia Pratiwis, Husnul Khadijah $7^{\star}$, Fajar Saljian Sanis, Padmi Riwandhany9 , M. Januarrizky Awid P9, 10Maiser Syaputra

\author{
1Program Studi Pendidikan Guru Sekolah Dasar, Universitas Mataram \\ Fatepa Universitas Mataram \\ 10Prodi Kehutanan Universitas Mataram \\ ${ }^{*}$ Co-Author : husnullkhadijah1701@gmail.com
}

\begin{abstract}
ABSTRAK. Program Kuliah Kerja Nyata $(\mathrm{KKN})$ yang bertemakan Administrasi Kependudukan (ADMINDUK) ini dirancang dalam upaya mendorong keterlibatan Perguruan Tinggi dalam mewujudkan kelengkapan identitas masyarakat dan sistem informasi yang terintegrasi sehingga dapat mengurangi permasalahan di bidang data kependudukan yang menjadi permasalahan di Desa/Dusun. Permasalahan utama yang ingin dipecahkan di Desa Senaru itu sendiri berkaitan dengan Data Adminstrasi Kependudukan (ADMINDUK). Hal ini dikarenakan Desa Senaru merupakan wilayah yang terbilang paling jauh dari pusat kota, sehingga kemungkinan besar sangat sedikit masyarakat yang sadar akan pentingnya kepemilikan dokumen kependudukan. Metode pengumpulaan data yang dilakukan dengan cara door to door untuk mempercepat pengumpulan data kependudukan agar dokumen kependudukan yang dibutuhkan dapat segera diperoses sehingga masyarakat dapat memiliki dokemen kependudukan yang mereka butuhkan dengan cepat. Jumlah KK yang tercetak sebanyak 14 dokumen, E-KTP sebanyak 17 dokumen, Akta Kelahiran sebanyak 38 dokumen, Akta Kematian sebanyak 5 dokumen dan untuk KIA tidak dapat tercetak karena blangko kosong tetapi jumlah dokumen yang dikumpulkan yaitu sebanyak 533 dokumen.
\end{abstract}

Kata Kunci: Pencatatan, Sistem Informasi, ADMINDUK, Desa Senaru

ABSTRACT. Kuliah Kerja Nyata (KKN) Program is designed to encourage higher education involvement in realizing the completeness of public identity and integrated information system so as to reduce problems in population data area which is the problem in village/Dusun. The main problem that you want to solve in Senaru village itself is related to the population Administration Data (ADMINDUK). This is because Senaru village is a region that is quite far from the city center, so there are very few people who are aware of the importance of ownership of the population documents. The method of collecting data is done by means of door to door to accelerate the collection of population data so that the needed population documents can be immediately diperoses so that the community can have a population management that they need quickly. Number of numbers issued by 14 documents, E-KTP as many as 17 documents, birth certificate as many as 38 documents, death deed as many as 5 documents and for KIA can not be printed because the empty printing but the number of documents collected is as many as 533 documents. .

Keyword: Recording, information system, ADMINDUK, Senaru village 


\section{PENDAHULUAN}

Kuliah Kerja Nyata (KKN) Tematik merupakan salah satu bentuk pengabdian kepada masyarakat yang dilakukan oleh mahasiswa secara interdisipliner, institusional dan kemitraan sebagai salah satu wujud implementasi Tri Dharma Perguruan Tinggi. Sejak tahun 2006 KKN Tematik Kontekstual berubah menjadi KKN Pembelajaran. Pemberdayaan Masyarakat sebagai proses pembelajaran bagi mahasiswa sekaligus wahana pemberdayaan masyarakat. Pola ini direncanakan dan dilaksanakan secara sistematis berdasarkan tema yang digali dari potensi masyarakat, dirumuskan, dan dilaksanakan bersama masyarakat. Hal ini diharapkan dapat memacu kemampuan masyarakat dalam pengembangan diri dan wilayah sehingga kesejahteraannya meningkat. Program Kuliah Kerja Nyata (KKN) yang bertemakan Administrasi Kependudukan (ADMINDUK) ini dirancang dalam upaya mendorong keterlibatan Perguruan Tinggi dalam mewujudkan kelengkapan identitas masyarakat. Selain itu tujuan dari Kuliah Kerja Nyata (KKN) Administrasi kependudukan ini adalah untuk menata sistem administrasi desa, melengkapi seluruh data desa kedalam sistem komputer dan memberikan pelayanan administrasi kependudukan kepada masyarakat.

Administrasi kependudukan adalah rangkaian kegiatan penataan dan penertiban dalam penerbitan dokumen dan data kependudukan melalui pendaftaran penduduk, pencatatan sipil, pengelolaan informasi Administrasi kependudukan serta pendayagunaan hasilnya untuk pelayanan publik dan pembangunan sektor lain. Administrasi kependudukan mencakup 3 (tiga) komponen yaitu: 1) kegiatan penataan dan penertiban dalam penerbitan dokumen dan data kependudukan melalui pendaftaran penduduk, 2) kegiatan penataan dan penertiban dalam penerbitan dokumen dan data kependudukan melalui pencatatan sipil; dan 3) kegiatan penataan dan penertiban dalam penerbitan dokumen dan data kependudukan melalui pengelolaan informasi administrasi kependudukan serta pendayagunaan hasilnya untuk pelayanan publik dan pembangunan sektor lain (Bappenas, 2009). $\quad$ Sedangkan Dokumen Kependudukan adalah dokumen resmi yang diterbitkan oleh Instansi Pelaksana yang mempunyai kekuatan hukum sebagai alat bukti autentik yang dihasilkan dari pelayanan Pendaftaran Penduduk dan Pencatatan Sipil. Dokumen Kependudukan meliputi; biodata Penduduk, KK, KTP, surat keterangan kependudukan dan Akta Pencatatan Sipil.

Penerapan SIAK adalah penerapan suatu sistem informasi administrasi kependudukan yang didalamnya mengelola data-data kependudukan dimana data-data tersebut dianggap sangat penting sebagai identitas diri maupun keterangan data kehidupan. SIAK dikembangkan berdasarkan prosedur-prosedur pelayanan administrasi kependudukan dengan menerapkan sistem teknologi informasi dan komunikasi guna menata sistem administrasi kependudukan di Indonesia. SIAK melayani pendaftaran penduduk dan pencatatan sipil berdasarkan peristiwa penting yang dialami oleh penduduk sejak lahir hingga meninggal dunia. Data kependudukan yang tersimpan dalam basis data yang keluarannya antara lain yaitu NIK, KK, E-KTP, Akta Kelahiran, Akta Kematian dan sebagainnya. Sedangkan Data Kependudukan adalah data perseorangan dan/atau data agregat yang terstruktur sebagai hasil dari kegiatan Pendaftaran Penduduk dan Pencatatan Sipil. Data Kependudukan terdiri atas data perseorangan dan/atau data agregat Penduduk. Data perseorangan meliputi; nomor KK, NIK, nama lengkap, jenis kelamin, tempat lahir, tanggal/bulan/tahun lahir, golongan darah, agama/kepercayaan, status perkawinan, status hubungan dalam keluarga, cacat fisik dan/atau mental, pendidikan terakhir, jenis pekerjaan, NIK ibu kandung, nama lbu kandung, NIK ayah, nama ayah, alamat sebelumnya, alamat sekarang, kepemilikan akta kelahiran/surat kenal lahir, nomor akta kelahiran/nomor surat kenal lahir, 
kepemilikan akta perkawinan/buku nikah, nomor akta perkawinan/buku nikah, tanggal perkawinan, kepemilikan akta perceraian, nomor akta perceraian/surat cerai, tanggal perceraian. Data agregat meliputi himpunan data perseorangan yang berupa data kuantitatif dan data kualitatif.

\section{ANALISIS PERMASALAHAN}

Berdasarkan temuan di lapangan banyak masyarakat yang belum melengkapi dokumen kependudukan khusunya di desa Senaru. Sehingga diperlukan fasilitator untuk membantu percepatan pelayanan masyarakat desa dalam melengkapi dokumen-dokumen resmi yang wajib dimiliki dengan berbagai macam inovasi yang diterapkan demi mewujudkan kesejahteraan masyarakat. Kegiatan KKN ini berjudul "Pelaksanaan Pencatatan Dokumen Keluarga Berbasis Sistem Informasi Administrasi Kependudukan (SIAK) dalam Mewujudkan tertib Administrasi Kependudukan di Desa Senaru." Judul ini dipilih untuk memfasilitasi percepatan pelayanan masyarakat desa dalam melengkapi dokumen-dokumen resmi yang wajib mereka miliki dengan berbagai macam inovasi yang kami terapkan demi mewujudkan kesejahteraan masyarakat.

\section{SOLUSI YANG DITAWARKAN}

Guna menngatasi permasalahan diatas, dirumuskan langkah alternatif solusi oleh tim pengabdian. Adapun rincian langkahnya yaitu: (1) 1. Pemetaan; (2) sosialisasi Tentang Pentingnya ADMINDUK; (3) Pengumpulan Berkas; (4) Pengantaran Berkas Lengkap; (5) Pengambilan Data Kependudukan; dan (6) Distribusi.

Langkah pertama yang dilakukan yaitu pemetaan. Melakukan pemetaan terhadap masyarakat Desa Senaru yang belum tuntas Administrasi Kependudukan (ADMINDUK). Dikarenakan wilayah Desa Senaru yang sangat luas sebesar $4.162 \mathrm{Ha}$ dan terdapat 15 dusun dengan kontur geografis yang berbeda- beda dimana terdapat lima dusun yang berada di pinggir jalan raya utama serta 10 dusun lainnya berada pedalaman.

Langkah kedua yang dilakukan yaitu Sosialisasi Tentang Pentingnya ADMINDUK. Mengadakan kegiatan sosialisasi tentang pentingnya masyarakat tuntas ADMINDUK untuk para perangkat desa dan para kepala dusun serta sosialisasi kegiatan yang akan dilaksanakan oleh tim KKN selama 45 hari. Dimana pada kegiatan tersebut kami bekerjasama dengan pihak Desa Senaru serta dengan pendampingan Dosen Pembimbing Lapangan.

Langkah ketiga yang dilakukan yaitu Pengumpulan Berkas. Pengumpulan berkas dilakukan dengan terjun langsung ke masyarakat serta pendampingan agar masyarakat yang memiliki berkas pendataan yang kurang dapat dengan cepat dilengkapi sehingga data kependudukan yang ingin dibuat dapat diperoses dengan cepat. Serta pada akhir masa kerja kami memberikan papan data kependudukan kepada desa.

Langkah keempat yang dilakukan yaitu Pengantaran Berkas Lengkap.Berkas kependudukan yang telah memenuhi persyaratan selanjutnya diantar ke kantor Camat Bayan dan kator Dukcapil. Berkas KK, Akta Kelahiran, E-KTP, dan Kartu KIA diantarkan ke kantor Camat Bayan sedangkan untuk berkas Akta Kematian diantar langsung ke kantor Dukcapil di Gondang.

Langkah kelima yang dilakukan yaitu Pengambilan Data Kependudukan. Data Kependudukan yang telah tercetak kemudian diambil, dipilah dan dicatat dokumen yang telah tercetak oleh mahasiswa KKN berdasarkan dusun sebelum kemudian diantarkan kepada pemilik dokumen yang tercetak.

Langkah keenam yang dilakukan yaitu Distribusi. Data kependudukan yang telah tercetak seperti KK, Akta Kelahiran, E-KTP, dan Akta Kematian kemudian diserahkan kepada masyarakat yang dokumennya telah tercetak. 


\section{HASIL DAN PEMBAHASAN}

Program Kerja ini dilaksanakan selama 45 hari di Desa Senaru Kecamatan Bayan Kabupaten Lombok Utara. Konsep dari program tersebut ialah pencatatan dokumen kependudukan seperti Kartu Keluarga, Akta Kelahiran, E-KTP, Kartu Identitas Anak (KIA), dan Akta Kematian. pada kegiatan KKN Tematik yang dilaksanakan kami berhasil membantu warga dalam pembuatan beberapa dokumen ADMINDUK yakni meliputi Kartu Keluarga sebanyak 14 dokumen, Akta Kelahiran sebanyak 38 dokumen, E-KTP sebanyak 17 dokumen, Akta Kematian sebanyak 5 dokumen, dan untuk KIA tidak sampai pada proses pencetakan dikarekan hambatan blanko yang kosong, sehingga hanya bisa sampai ke pengumpulan dokumen yang diantarkan langsung ke Kantor Camat Bayan dan Kantor Dinas Kependudukan dan Pencatatan Sipil Kabupaten Lombok Utara. Jumlah berkas yang dikumpulkan sebanyak 533 dokumen.

Adapun Langkah-langkah yang digunakan dalam pengumpulan berkas yaitu: Melakukan pemetaan terhadap masyarakat desa Senaru yang belum tuntas Administrasi Kependudukan (ADMINDUK). Pemetaan ini dilakukan dikumpulkan sebanyak 533 dokumen.

Setelah masyarakat difasilitasi dalam pengumpulan berkas maka berkas-berkas yang sudah lengkap dan sesuai dengan persyaratan makan akan di antar ke Kecamatan dan ke Dukcapil. Adapun berkas yang diantara ke kecamatan meliputi berkas Kartu Keluarga, Akta Kelahiran, KTP Elektronik, dan Kartu Identitas Anak (KIA). Sedangkan berkas Akta Kematian diantarkan Ke Dukcapil. Setelah berkas tercetak langkah selanjunya yaitu pendistribusian berkas kepada masyarakat.

Beberapa kendala yang dihadapi pada saat pengumpulan berkas kependudukan meliputi tidak tersedianya blangko dalam pembuatan KIA sehingga sampai akhir kegiatan KKN Kartu Identitas Anak tidak dapat tercetak. Kendala dalam pembuatan E- KTP yaitu blangko E-KTP habis sehingga masyarakat hanya sampai perekaman saja. Kendala yang dihadapi dalam pembuatan Akta Kelahiran yaitu berkas akta kelahiran menumpuk di kecamatan dikarenakan komputer yang digunakan untuk menginput data mengalami kerusakan sehingga berkas yang sudah lengkap tidak bisa dikerjakan. Hambatan lain dalam pembuatan Akta Kelahiran yaitu orangtua yang tidak memiliki buku nikah maka harus membuat surat pernyataan sebagai pasangan suami istri sehingga terkadang masyarakat tidak mengurusnya. Kendala dalam Pengumpulan berkas Akta Kematian yaitu kurangnya sosialisasi dan kesadaran masyarakat tentang kegunaan dari Akta Kematian sehingga masyarakat tidak tertarik untuk membuat Akta Kematian. Kendala dalam pengumpulan berkas Kartu Keluarga yaitu buku nikah, jika tidak memiliki buku nikah maka harus membuat surat pernyataan sebagai pasangan suami istri sehingga terkadang masyarakat tidak mengurusnya.

\section{KESIMPULAN}

Berdasarkan program yang telah dijalankan selama 45 hari di Desa Senaru dapat disimpulkan bahwa secara umum kegiatan pencatatan dokumen keluarga berbasis sistem informasi administrasi kependudukan (SIAK) dalam mewujudkan tertib administrasi kependudukan di Desa Senaru berjalan dengan lancar dan terkoordinasi dengan baik disetiap tahapannya. Adapun Jumlah dokumen yang berhasil tercetak dalam pembuatan beberapa dokumen ADMINDUK yakni meliputi Kartu Keluarga sebanyak 14 dokummen, Akta Kelahiran sebanyak 38 dokumen, E- KTP sebanyak 17 dokumen, Akta Kematian sebanyak 5 dokumen, dan untuk KIA tidak sampai pada proses pencetakan dikarekan hambatan blanko yang kosong, sehingga hanya sampai ke pengumpulan dokumen dengan jumlah dokumen sebanyak 533 dokumen. Kelompok 
kami berhasil memberikan arahan untuk perbaikan sistem administrasi kependudukan, melengkapi beberapa dokumen kependudukan seperti KK, Akta Kelahiran, E-KTP, KIA dan Akta Kematian dan membantu serta mendampingi masyarakat dalam kepengurusan administrasi kependudukan dari 5 (lima)dokumen kependudukan yang kami kerjakan.

\section{UCAPAN TERIMA KASIH}

Adapun program ini terlaksana dengan lancer dikarena semua pihak ikut terlibat dalam kegiatan yang telah dilakukan. Sehingga ucapan terima kasih sangat pantas disematkan kepada :

1. Bapak Maiser Syaputra S.Hut,.M.Si selaku DPL (Dosen Pembimbing Lapangan).

2. Bapak Raden Akria Buana selaku kepala Desa Senaru.

3. Bapak Suhardi selaku kepala dusun Batu Koq, Bapak Mistrana selaku kepada dusun Senaru,

4. Bapak Husni selaku kepala dusun Tumpang Sari, Bapak Effendi selaku kepala dusun Lokok Kelungkung, Bapak Eka selaku kepala dusun Magling.

5. Bapak Arifin selaku kabid Dinas Dukcapil Kabupaten Lombok Utara

6. Bapak Agus selaku pegawai Dinas Dukcapil Kabupaten Lombok Utara

7. Ibu Nurulbayati selaku pegawai Dinas Dukcapil Kabupaten Lombok Utara

8. Ibu Vera selaku pegawai Dinas Dukcapil Kabupaten Lombok Utara

\section{REFERENSI}

Bappenas. 2009. Pedoman Pelaksana Pamsimas Masyarakat. Jakarta: PAMSIMAS

Peraturan Menteri Dalam Negeri Nomor 7 Tahun 2019 Tentang Pelayanan Administrasi Kependudukan Secara Daring

Perauran Menteri Dalam Negeri Nomor 54 Tahun 1999 Tentang Penyelenggaraan Pendaftaran Penduduk Undang-Undang Nomor 23 Tahun 2006 